\title{
REPRESENTASI MASKULINITAS TOKOH UTAMA DALAM FILM PERSAHABATAN BAGAI KEPOMPONG 2021
}

\author{
Annisa Fitria Ramadhani ${ }^{1}$ Catur Suratnoaji ${ }^{1}$
}

1Jurusan IImu Komunikasi, Fakultas IImu Sosial Dan IImu Politik Universitas Pembangunan Nasional "Veteran" Jawa Timur

Jalan Rungkut Madya No.01, Kota Surabay, 60294, Indonesia

Correspondence:

Annisa Fitria Ramadhani frannisa2@gmail.Com
Abstract: The research aims to illustrate and understand the meaning of the representation of masculinity of the main character in the film "Friendship Like a Cocoon" directed by Sentot Sahid. This research is qualitative research using primary and secondary data collection techniques obtained from reference books, scientific journals, and articles. The study used an analysis of Roland Barthes' Semiotics data that had three levels of tagging: denotation, connotation, and myth that focused on seven characteristics of masculinity expressed by Janet Saltzman Chafetz, namely: 1) Male Physical Appearance, 2) Male Functional, 3) Male Sexual, 4) Male Emotions, 5) Male Intellectuals, 6) Male Interpersonal, and 7) Male Personal Character.

Keywords: Film, Janet Saltzman Chafetz's Concept of Masculinity, Semiotics Roland Barthes.

\begin{abstract}
Abstrak: Penelitian ini bertujuan untuk menggambarkan dan memahami makna representasi maskulinitas tokoh utama dalam film "Persahabatan Bagai Kepompong" yang disutradarai oleh Sentot Sahid. Penelitian ini adalah penelitian kualitatif dengan menggunakan teknik pengumpulan data primer dan sekunder yang didapatkan dari film Persahabatan Bagai Kepompong, referensi buku, jurnal ilmiah, dan artikel. Penelitian ini menggunakan analisis data semiotika Roland Barthes yang memiliki tiga tingkat penandaan yaitu denotasi, konotasi, dan mitos yang difokuskan pada tujuh karakteristik maskulinitas yang diutarakan oleh Janet Saltzman Chafetz, yaitu : 1) Penampilan Fisik Laki-Laki, 2) Fungsional Laki-Laki, 3) Seksual Laki-Laki, 4) Emosi LakiLaki, 5) Intelektual Laki-Laki, 6) Interpersonal Laki-Laki, dan 7) Karakter Personal Laki-Laki.
\end{abstract}

Kata Kunci : Film, Konsep Maskulinitas Janet Saltzman Chafetz, Semiotika Roland Barthes. 


\section{1 | PENDAHULUAN}

Penyampaian pesan dapat dilakukan dimana saja dan kapan saja. Penyampaian pesan dapat disampaikan melalui tayangan televisi, siaran radio, iklan, film, surat kabar, majalah, hingga media sosial. Salah satu bentuk komunikasi yang dapat menyalurkan pesan kepada khalayak secara cepat dan serentak adalah komunikasi massa. Baran menyebutkan komunikasi massa adalah proses penciptaan makna bersama antara media massa dan khalayakanya (Fadaq, 2017). DeFleur dan Dennis menjelaskan bahwa komunikasi massa sebagai proses komunikasi yang ditandai oleh adanya penggunaan media terhadap komunikatornya guna menyebarkan informasi secara luas dan terus-menerus yang diharapkan dapat mempersuasi khalayak luas. Dalam proses penyampaian pesannya, komunikasi massa membutuhkan gatekeeper untuk memudahkan masyarakat agar bisa mendapatkan dan memahami isi pesan yang disampaikan dengan mudah melalui sebuah media.

Kehadiran teknologi tidak dapat terlepas dari perkembangan media massa. Media massa merupakan sarana komunikasi yang dapat menjangkau khalayak sebanyak mungkin. Perkembangan yang pesat pada media massa sebagai sumber informasi, sarana penyampaian pesan, fungsi pendidikan dan hiburan memang sudah menjadi daya tarik tersendiri bagi masyarakat. Penggunaan media baru juga merupakan tren yang menjadi komodifikasi (Setiyaningsih, \& Jatmikowati, 2019) dan mampu menyebabkan kepanikan (Setiyaningsih, 2020). Sehingga hal tersebut dapat berdampak pada sisi positif maupun sisi negatif. Film merupakan salah satu platform media massa yang banyak diminati oleh masyarakat dari berbagai macam kalangan, mulai dari anakanak hingga dewasa. Film dapat merepresentasikan realitas yang ada di dalam masyarakat. Dalam Dicky, (2016) sebagai representasi dari realitas, film membentuk dan menghadirkan kembali realitas berdasarkan kode-kode, konveksi-konveksi, dan ideologi kebudayaan. Desain pesan penggunaan media baru berbasis teknologi dapat meningkatkan penjualan di berbagai bentuk media (Triono \& Setiyaningsih, 2017).Dalam semua genre film, masing-masing karakter baik perempuan maupun laki-laki akan memiliki peran dan ciri yang berbeda. Peran atau ciri tersebut disebut feminitas untuk perempuan dan maskulintas untuk laki-laki.

Maskulinitas merupakan konsep tentang peran sosial, perilaku, dan makna yang dilekatkan pada laki-laki di waktu tertentu. Hal tersebut berarti maskulinitas mempunyai sifat yang statis dan dapat mengalami perubahan makna sesuai dengan keadaan sekitar. Konsep maskulinitas masih dianggap sebagai fenomena yang semu dalam lingkungan masyarakat. Dalam Budiastuti \& Wulan (2014), ide tentang kelelakian masih sering dianggap sebagai suatu konsep yang secara sosial tidak banyak dibatasi. Pernyataan tersebut mengacu pada hal-hal yang sudah dipersepsikan sebagai halhal yang tidak dapat dipisahkan dari laki-laki dianggap sebagai sifat positif yang harus dimiliki, misalnya ketampanan, kekuatan, keberanian, ketangguhan dan sifat-sifat lainnya yang dikaitkan dengan identitas laki-laki ideal. Hal tersebut dikarenakan konsep maskulinitas termasuk sebuah konstruksi sosial yang dapat berubah-ubah, tergantung dengan perkembangannya dalam kondisi sosial-budaya masyarakat. Sifat maskulinitas pada laki-laki memang sudah melekat sejak dilahirkan, ditambah lagi dengan adanya tayangan media massa yang memperlihatkan sifat laki-laki dari segi kekuatan, gaya berbicara, dan gaya berpenampilan. Laki-laki yang tegar, kuat, pemberani, berotot, sukses, dan tidak menangis dapat dianggap sebagai laki-laki ideal atau sejati. Konsep maskulinitas seperti itu cenderung membuat laki-laki tidak pernah melihat perasaannya sendiri, merasa tertekan, bahkan merasa cemas karena terbebani oleh keinginan oranglain yang memaksa laki-laki untuk menjadi maskulin (Setiyaningsih et al., 2021).

Konsep maskulinitas dalam setiap budaya berbeda-beda. Maskulinitas budaya timur terbentuk dan dipengaruhi oleh faktor kebudayaan melalui berbagai aturan dan kewajiban yang diajarkan. Dalam Syulhajji S, (2017) berpendapat bahwa berbagai aturan dan atribut budaya dapat diterima melalui berbagai macam media, seperti ritual adat, agama, pola asuh orang tua, jenis permainan, 
tayangan televisi, dan buku bacaan yang diberikan oleh orang tua secara tidak langsung dapat membentuk citra diri seorang laki-laki dalam kehidupannya. Kondisi tersebut dapat ditunjukan dari cara berpakaian, cara berpenampilan, bentuk aktivitas yang dikerjakan, cara bergaul, cara menyelesaikan masalah, cara berekspresi secara verbal dan non verbal, hingga jenis aksesoris tubuh yang dipakai.

Psikologi Janet Saltzman Chafetz mengemukakan tujuh konsep karakteristik maskulinitas dalam tataran masyarakat, yaitu : Penampilan Fisik Laki-Laki, Fungsional Laki-Laki, Seksual LakiLaki, Emosional Laki-Laki, Intelektual Laki-Laki, Interpersonal Laki-Laki, Dan Karakter Personal LakiLaki (Sari et al., 2019). Sedangkan David dan Brannon memaparkan sifat-sifat maskulinitas, yaitu : No Sissy Stuff, Be A Big Wheel, Be A Sturdy Oak, Give Em Hell, New Man As Nurturer, New Man As Narcissist, Macho Dan Hologanism, serta Metroseksual. Adapun konsep maskulinitas baru yang disebut Soft Masculinity. Konsep tersebut dibentuk oleh media Korea melalui K-Pop dengan cara menggabungkan old masculinity dan asian-masculinity (Pratami \& Prima, 2020). Sedangkan menurut Gosling Soft masculinity adalahs produk hibrida yang dibangun melalui penggabungan maskulinitas seonbi tradisional Korea Selatan (yang dipengaruhi oleh maskulinitas Konfusianisme Cina), maskulinitas bishonen Jepang (bocah laki-laki), dan maskulinitas metroseksual global (Yusanta, 2019).

Proses transformasi remaja dapat berpengaruh dalam faktor sosial yang disebabkan oleh norma gender yang dianut oleh orang dewasa. Selain itu, melalui pemikiran dan karakteristik masyarakat yang terbuka dapat menjadikan seorang remaja lebih mudah menyerap unsur budaya baru. John W. Santrock mengemukakan bahwa remaja diartikan sebagai masa perkembangan transisi antara masa anak dan masa dewasa yang mencakup perubahan biologis, kognitif dan sosialemosional (Nurhayati, 2016). Remaja akan selalu bertumbuh dan berkembang dalam suatu lingkungan yang memiliki suatu budaya tertentu yang harus dilestarikan. Budaya merupakan pola perilaku, keyakinan dan hal lain yang dihasilkan oleh suatu kelompok tertentu yang diwariskan dari suatu generasi ke generasi berikutnya. Maslow mengungkapkan bahwa kebutuhan psikologis dari individu akan muncul setelah kebutuhan-kebutuhan fisologisnya telah terpenuhi (Ryoningrat \& Herdiyanto, 2019). Kebutuhan-kebutuhan dasar individu tersebut adalah kebutuhan fisiologis, kebutuhan rasa aman dan tentram, kebutuhan untuk mendapatkan cinta dan rasa memiliki, dan kebutuhan akan rasa harga diri (self actualization).

Film Persahabatan Bagai Kepompong tayang pada tanggal 26 Februari 2021 di Disney Plus Hotstar. Film ini merupakan film drama remaja Indonesia yang diadaptasi dari cerita sinetron Kepompong yang tayang di SCTV pada tahun 2008. Film Persahabatan Bagai Kepompong menampilkan konsep dan warna yang berbeda dari sinetron sebelumnya. Film ini difokuskan pada masalah pembullyan yang terjadi dikalangan remaja. Dalam film ini tokoh utama yaitu Ben Sarjono digambarakan mempunyai sifat maskulinitas yang berbeda dibandingkan dengan sifat laki-laki pada umumnya. Ben merupakan seorang anak laki-laki kutu buku yang pandai dan kreatif. Penampilannya digambarkan sebagai sosok laki-laki yang lembut, lemah, cupu, mudah baper, individualis, pasrah dengan keadaan, gengsi, tertutup, dan penakut.

Berdasarkan uraian di atas, maka penulis membutuhkan sebuah ilmu yang mendasar untuk meneliti sebuah film yaitu Semiotika. Semiotika dikemukakan oleh beberapa ahli, salah satunya adalah Roland Barthes. Roland Barthes mendefinisikan semiotika sebagai suatu hubungan antara tanda denotasi, konotasi, dan mitos. Makna denotasi adalah makna paling nyata dari tingkat pertandaan yang menjelaskan hubungan antara penanda dan petanda yang menghasilkan makna yang jelas atau eksplisit. Makna konotasi adalah signifikasi tahap kedua yang berhubungan dengan isi yang menjelaskan hubungan antara penanda dan petanda yang menghasilkan makna yang bersifat tersembunyi atau implisit. Mitos adalah kebudayaan yang menjelaskan atau memahami beberapa aspek tentang realitas. Setelah sistem tanda-penanda-petanda terbentuk, maka akan 
membentuk tanda baru, yaitu penanda kedua dan petanda kedua. Mitos dalam semiotika dianggap sebagai proses pemaknaan yang tidak terlalu mendalam, karena hanya berfungsi untuk merepresentasikan makna yang terlihat.

Penulis memilih film Persahabatan Bagai Kepompong untuk memberikan pemahaman tentang konsep maskulinitas remaja dan mengetahui tanda-tanda maskulinitas tokoh utama yang dirasa memiliki gambaran maskulinitas yang berbeda dengan penggambaran maskulinitas laki-laki pada umumnya. Penulis menggunakan Semiotika Roland Barthes yang didasari dengan tujuh konsep maskulinitas Janet Saltman Chafetz sebagai acuan penelitian untuk melihat hubungan antara suatu tanda dengan objeknya, sehingga penulis dapat memberikan pemaknaan tanda-tanda maskulinitas dan menggambarkan representasi maskulinitas yang terbentuk dalam tokoh Ben Sarjono dalam film Persahabatan Bagai Kepompong tahun 2021.

\section{2 | METODE PENELITIAN}

Metodologi yang digunakan dalam penelitian ini adalah kualitatif menggunakan analisis Semiotika Roland Barthes. Dalam peta tanda Semiotika Roland Barthes pemaknaan terjadi dalam dua tahap. Pada tahap pertama (3) terdapat penanda (1) dan petanda (2) yang menyatu sehingga membentuk penanda pada tahap kedua (4). Pada tahap selanjutnya, penanda (4) dan petanda (6) yang telah menyatu membentuk petanda baru (5) yang dianggap sebagai perluasan makna.

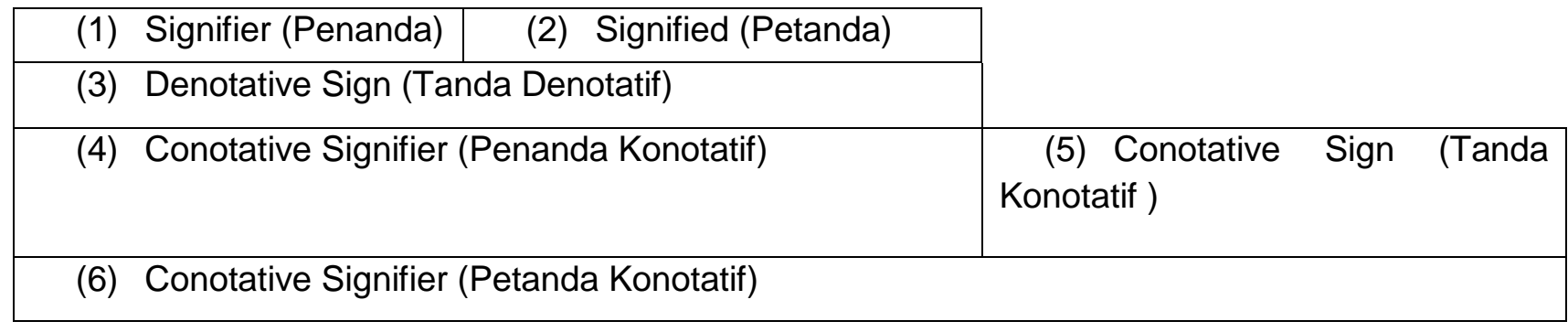

Gambar 1. Peta Tanda Roland Barthes (Istanti, 2021)

Penelitian ini menggunakan jenis penelitian kualitatif untuk menganalisis, mencari, dan memahami tanda dan makna secara mendalam terhadap maskulinitas Ben Sarjono dalam film Persahabatan Bagai Kepompong. Metode penelitian menggunakan metode semiotika Roland Barthes karena metode semiotika merupakan sebuah ilmu yang berhubungan dengan tanda yang dapat digunakan untuk meneliti film, iklan, novel, drama, dan fashion. Selain itu, Roland Barthes tidak hanya mengartikan sebuah makna ke dalam rangkaian bahasa saja, tetapi juga menyisipkan unsur ideologi serta budaya. Maka dari itu, penulis menggunakan metode semiotika Roland Barthes untuk mencari tanda-tanda pada film Persahabatan Bagai Kepompong dengan cara mencari pemenggalan adegan dan menentukan ke dalam tiga tingkat penandaan yaitu denotasi, konotasi dan mitos.

Teknik pengumpulan data dalam penelitian ini adalah landasan teori yang didapatkan penulis dari referensi-referensi buku, jurnal ilmiah, artikel dan situs internet. Selanjutnya, penulis akan menonton dan mendengarkan film Persahabatan Bagai Kepompong secara saksama dan berulangulang, kemudian penulis akan menyimak serta mencatat untuk mendapatkan data berupa gambar dan dialog tokoh yang dapat dijadikan sebagai sumber data penelitian.

Dalam teknik analisis data, penulis akan menganalisis gambaran maskulinitas tokoh utama dalam film Persahabatan Bagai Kepompong. Penulis akan mencari dan mendeskripsikan tandatanda maskulinitas tokoh utama terlebih dahulu sesuai dengan tujuh konsep karakteristik 
maskulinitas Janet Saltzman Chafezt, lalu menganalisis menggunakan Semiotika Roland Barthes. Penulis akan mengamati secara menyeluruh agar mendapatkan penjelasan makna yang sesuai dengan tiga tingkat penandaan yaitu denotasi, konotasi dan mitos.

\section{3 | HASIL DAN PEMBAHASAN}

Dalam penggambaran film, telah banyak ditunjukan beberapa aktivitas tokoh utama. Sesuai dengan tujuan penelitian ini, maka penulis akan mengambil beberapa adegan yang berkaitan dengan tujuh karakteristik maskulinitas menurut Janet Saltzman Chafezt, yaitu sebagai berikut.

\section{Representasi Penampilan Fisik Tokoh Ben Dalam Film Persahabatan Bagai Kepompong}

Penampilan fisik merupakan tanda-tanda yang dapat menjadi identitas seseorang. Menurut konsep Janet Saltzman Chafetz, maskulinitas dapat dilihat dari Penampilan Fisik Laki-Laki Tradisional, yaitu memiliki kekuatan didalamnya, seperti : tampan, berani, jantan, kuat, atletis, dan tidak peduli terhadap penampilan hingga proses penuaan. Menurut Kustiawan (dalam Rosi, 2018) "Masa remaja adalah masa peralihan dari anak-anak menjadi dewasa dan disertai dengan perubahan hormon, emosi, penilaian, bentuk fisik, dan tahap pembentukan identitas diri”. Secara fisik remaja akan mengalami perubahan seperti bertambahnya tinggi badan, berat badan, dan perubahan ciri-ciri fisik yang dapat dilihat.

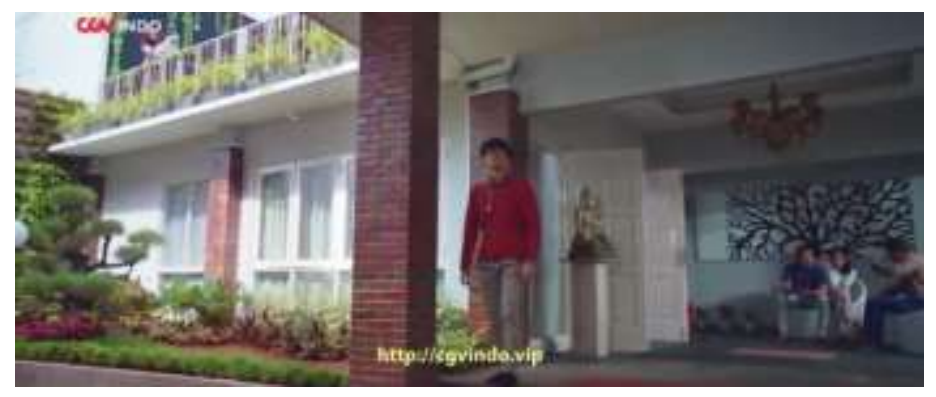

\section{Gambar 2. Penampilan Fisik Ben}

Makna denotasi dalam potongan adegan ini menunjukan penampilan fisik Ben yang tergolong bertubuh tinggi. Salah satu indikasi karakteristik laki-laki adalah tinggi dan berat badan yang ideal. Menurut Organisasi Kesehatan Dunia dalam Height For Age Boys 5 - 19 years (Makarim, 2021), tinggi ideal anak laki-laki. Untuk usia 14 tahun tingginya sekitar 163,2 cm. Dalam film Persahabatan Bagai Kepompong, Ben Sarjono adalah seorang anak laki-laki berusia 14 tahun yang sedang menempuh pendidikan tingkat sekolah menengah pertama kelas 9. Tokoh Ben Sarjono diperankan oleh Bio one yang mempunyai tampilan fisik, yaitu dada membidang dan lebar, alis tebal, kumis tipis, rambut cepak rapi, berkulit putih, bersih, dan terawat dengan tinggi badan $168 \mathrm{~cm}$. Sesuai dengan tabel di atas, usia anak 14 tahun dengan tinggi $168 \mathrm{~cm}$ masuk dalam kategori tinggi yang ideal.

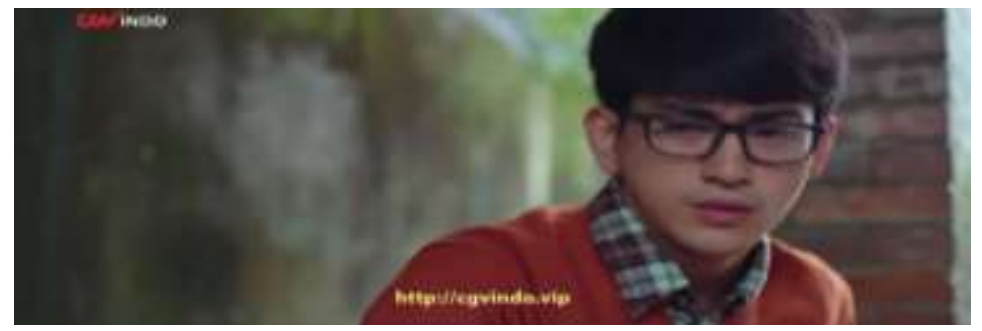

Gambar 3. Gaya Berpakaian Ben Menggunakan Hem dan Sweater 
Gaya berpakaian merupakan salah satu tanda-tanda yang dapat menunjukan ciri khas lakilaki remaja. Denotasi pada kostum yang dikenakan Ben adalah kemeja dengan sweater atau kaos dengan jaket yang dipadukan dengan celana jeans. Kemeja dan jeans adalah busana casual yang biasa digunakan oleh laki-laki remaja untuk datang ke acara formal maupun nonformal, karena gaya fashion tersebut tampak praktis dan terkesan santai. Adapun aksesoris yang digunakan Ben sebagai penunjang penampilan, yaitu jam tangan sebagai petunjuk waktu, kacamata untuk membantu pengelihatan, serta sepatu sneakers. Hal ini sesuai dengan konsep maskulinitas sebelum tahun 1990-an menurut Deborah David dan Robert Brannon, yaitu No Sissy Stuff yang artinya sesuatu yang berkaitan dengan hal-hal yang berbau feminin dilarang, seorang laki-laki sejati harus menghindari perilaku atau karakteristik yang berasosiasi dengan perempuan.

Seseorang yang berkacamata sering kali dianggap sebagai orang yang memiliki penyakit, yaitu kerusakan mata. Tetapi seiring dengan perkembangannya mode, penggunaan kacamata dapat dinilai dari segi bentuk dan model kacamata yang digunakan. Penggunaan kacamata tebal dapat dinilai sebagai orang yang pandai, lugu, dan suka membaca buku, sedangkan penggunaan kacamata dengan berbagai model frame lebih dikaitkan dengan fashion.

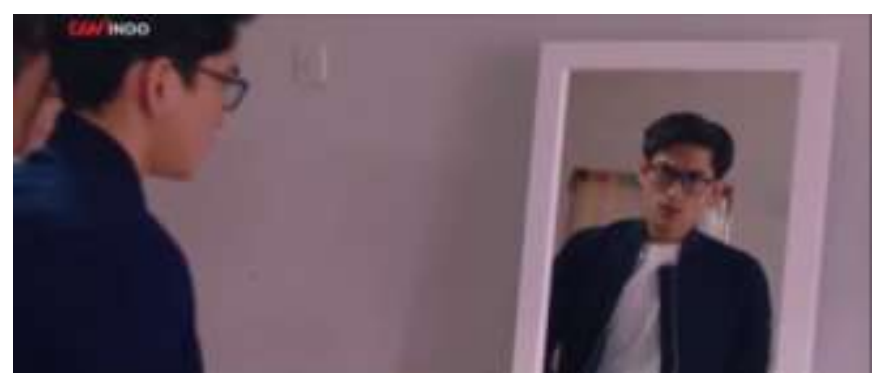

\section{Gambar 4. Gaya Berpakaian Ben Menggunakan Kaos Putih dan Jaket Hitam}

Makna konotasi dalam potongan adegan diatas menunjukan bahwa Ben sebagai laki-laki maskulin yang mengikuti perkembangan mode. Menurut Barthes (dalam Aryani, 2014), "Semiotika bekerja dengan cara bagaimana makna masuk ke dalam sebuah citra atau image". Bentuk tubuh dan kostum yang digunakan Ben merupakan sebuah penanda, semua mengacu pada representasi laki-laki maskulin. Penampilan fisik, pakaian, dan aksesoris yang digunakan Ben menunjukan bahwa sebagai laki-laki harus bisa menempatkan dan menyesuaikan diri dengan kondisi lingkungannya, sehingga harus mengikuti perkembangan mode sesuai dengan tingkatan status dan ekonominya.

Mitos dalam potongan adegan tersebut menunjukkan bahwa penampilan fisik Ben sebagai laki-laki maskulin. Laki-laki berkacamata dengan penampilan rapi dapat dikategorikan sebagai lakilaki maskulin karena hal tersebut dapat menunjang penampilan, membuat laki-laki dapat lebih disegani dan terlihat menarik. Penggunaan kostum dan aksesoris merupakan penanda. Menurut Barthes, semiotika bekerja dengan cara bagaimana makna masuk ke dalam sebuah citra atau image. Berdasarkan analisis diatas, penampilan fisik dan kostum yang digunakan tokoh Ben mengacu pada representasi laki-laki maskulin. Penanda tersebut telah menghasilkan petanda, yaitu penampilan fisik laki-laki remaja yang bergaya pakaian kelas menengah atas.

\section{Representasi Fungsional Tokoh Ben Dalam Film Persahabatan Bagai Kepompong}

Menurut konsep Janet Saltzman Chafetz, maskulinitas dapat dilihat dari Fungsional Laki-Laki Tradisional, yaitu posisi laki-laki sebagai tulang punggung dan pencari nafkah bagi kerabat dan dirinya. Fungsional merujuk pada aspek sosial yang ditinjau berdasarkan fungsinya. Literasi 
fungsional menyiratkan bahwa literasi dapat digunakan untuk meningkatkan kapasitas masyarakat, meraih tujuan, dan meningkatkan kemampuan diri. Menurut Cocchiarella (dalam Nurgiyantoro et al., 2020) "Literasi fungsional dapat dimaknai sebagai kompetensi dan keterampilan praktis yang dibutuhkan dalam kehidupan sosial dan berperan dalam kehidupan bermasyarakat". Kemampuan fungsional yang baik didasari pada kemampuan menulis (Sheperd \& Goggin, 2012), membaca pemahaman (Dolenc et al., 2015), dan juga dalam hal mengakses sumber informasi digital (Olaniran, 2020) (dalam Nurgiyantoro et al., 2020). Maka, dalam pembahasan fungsional remaja dapat diartikan bahwa fungsional mengacu pada bagaimana remaja bertanggungjawab sebagai pelajar dalam menjalankan tugas dan kewajibannya, menguasai keterampilan, peningkatan kualitas diri dan sosial dirinya dalam lingkungan hidupnya.

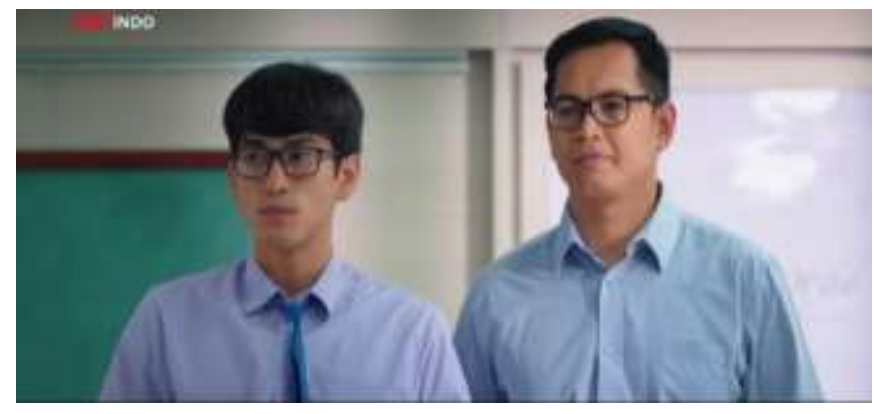

\section{Gambar 5. Ben Bersama Pak Aldi di Depan Kelas Menjelaskan Buku Max Havelar}

Makna denotasi dalam potongan adegan ini menampilkan Ben sedang memberi penjelasan kepada teman-teman di kelasnya tentang buku Max Havelaar. Dalam adegan ini terdapat percakapan :

Ben : "Max Havelaar ditulis oleh Multatuli yang bernama asli Eduard Douwes Dekker. Buku ini penting karena menggambarkan perlawanan rakyat jelata pada kaum penindas di jaman penjajahan Belanda".

Dalam percakapan diatas menunjukan bahwa Ben bisa menjadi teladan yang baik untuk teman-temannya, Ben dapat menginspirasi teman-temannya untuk terus membaca buku agar mendapatkan wawasan yang luas, berprestasi dan memahami kehidupan luar melalui buku bacaan.

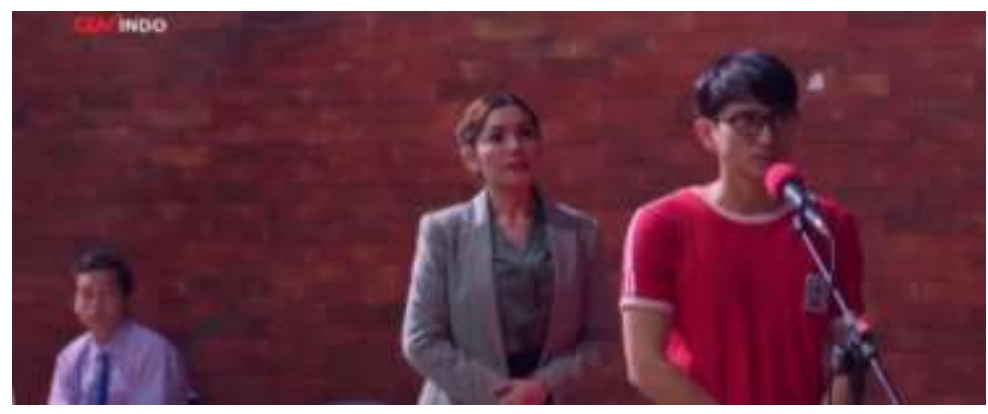

\section{Gambar 6. Ben Didampingi Presentasi Mengenai Konsep Proposal Perpisahan Sekolah}

Makna konotasi dalam potongan adegan ini, Ben sebagai laki-laki yang maskulin. Maskulinitas Ben ditunjukan sebagai seorang remaja yang telah menjalankan fungsinya sebagai murid. Ben memiliki kewajiban yaitu sekolah untuk mencapai prestasi agar bisa bertanggungjawab terhadap dirinya sendiri, mendapatkan pekerjaan, hingga menjadi orang yang sukses kedepannya. Rowena \& Rutherford (dalam Dewi, 2019) "Fungsional laki-laki tidak hanya mencukupi dari segi 
materil akan tetapi fungsional laki-laki lebih terlihat jika dia mampu bertanggungjawab akan dirinya, keluarga dan orang-orang disekitarnya".

\section{Representasi Seksualitas Tokoh Ben Dalam Film Persahabatan Bagai Kepompong}

Menurut konsep Janet Saltzman Chafetz, maskulinitas dapat dilihat dari seksual laki-laki yang mencakup pada pengalaman laki-laki dalam menjalin hubungan dengan perempuan, agresif dan berstatus lajang. Representasi seksualitas tidak harus ditunjukan dengan adegan romantis atau berhubungan seks. Menurut Chafezt (dalam Dewi, 2019) "Representasi seksualitas juga dapat ditunjukan dengan memperlihatkan sikap peduli dan perhatian terhadap perempuan.

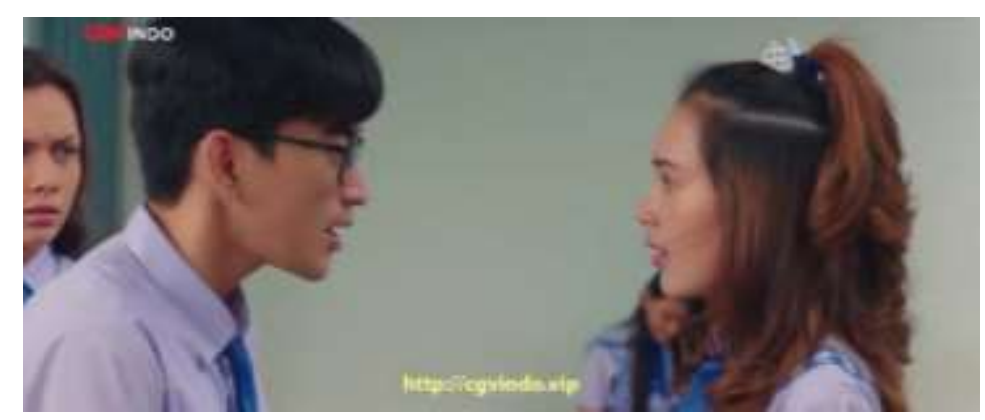

\section{Gambar 7. Awal Pertemuan Ben dan Paula}

Adapun percakapan yang terjadi dalam adegan ini yang menunjukan keberanian Ben saat berhadapan dengan lawan jenisnya. Ben : "Paula, maaf ya? Aku Ben". Makna denotasi dalam potongan adegan ini Ben menunjukan sifat agresifnya pada Paula dengan bersikap sigap menangkap Paula yang hampir jatuh ke lantai. Tidak hanya itu, Ben juga memperkenalkan dirinya sambari meminta maaf kepada Paula karena tidak sengaja menabrak jalannya. Pada saat itu, Paula langsung tersipu malu dan ingin berkenalan lebih dekat lagi dengan Ben. Hal ini menunjukan Ben sebagai laki-laki remaja yang normal yang tertarik pada lawan jenisnya. Ben mampu memulai pembicaraan dengan perempuan, mengajak berkenalan, dan tidak gengsi untuk meminta maaf.

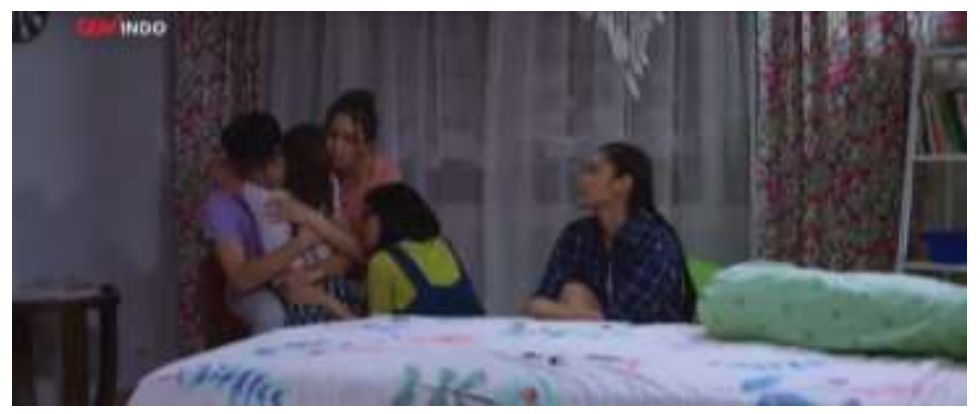

\section{Gambar 8. Ben dan Geng Kepompong Saling Berpelukan untuk Menenangkan Bembi}

Dalam adegan yang terjadi diatas terdapat percakapan yang menunjukan kelembutan dan ketegasan Ben terhadap perempuan.

Ben : "Bembi! Hapus air mata kamu kalo jelas-jelas kak Edo itu gak ngehargain kamu, buat apa kamu pertahanin? Masih banyak Edo-Edo yang lain yang bisa ngehargain kamu. Kamu baik, kamu cantik, kamu lucu, kamu asik. Jadi bego aja cowok yang gak bisa ngehargain kamu. lya kan ?" 
Makna konotasi dalam potongan adegan ini, menunjukan tokoh Ben sebagai laki-laki yang maskulin. Maskulinitas Ben ditampilkan sebagai yang tegas tetapi memiliki kelembutan saat berhadapan dengan perempuan. Ben berani mengungkapkan pendapatnya, memberikan rasa tenang, nasihat juga semangat kepada teman perempuannya. Hal ini juga sesuai dengan konsep Maskulinitas tahun 1980-an. Beynon mengemukakan konsep maskulinitas New man as nurturer, yaitu Laki-laki menjalani sifat alamiahnya seperti perempuan sebagai makhluk yang mempunyai rasa perhatian. Laki-laki mempunyai kelembutan sebagai seorang bapak, misalnya, untuk mengurus anak.

\section{Representasi Emosi Tokoh Ben Dalam Film Persahabatan Bagai Kepompong}

Menurut konsep Janet Saltzman Chafetz, maskulinitas dapat dilihat dari emosional laki-laki, yaitu laki-laki dapat mengendalikan dan menyembunyikan emosi yang dirasakan. Makna denotasi dalam potongan adegan ini menampilkan Ben sedang beradu mulut dengan Isabel. Hal tersebut terjadi karena Ben merasa kesal dan terganggu karena Isabel menyelinap diam-diam ke kamarnya. Meskipun telah terjadi pertengkaran diantara keduanya, Ben masih berusaha mengendalikan emosinya dengan tidak melakukan tindak kekerasan kepada Isabel. Ekspresi yang ditunjukan Ben adalah dahi berkerut, lubang hidung membesar, dan alis mengerut ke depan. Menurut Roland Barthes, ekspresi merupakan salah satu bentuk dari suatu tanda.

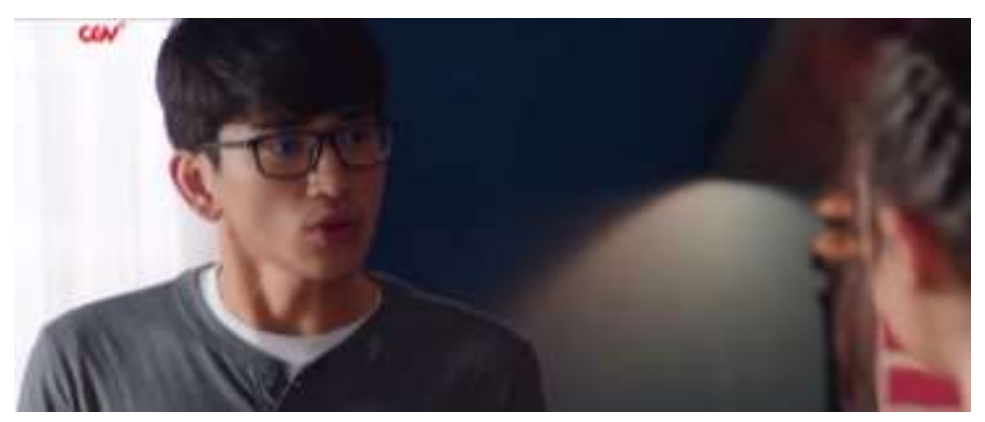

\section{Gambar 9. Ben Beradu Mulut Dengan Isabel}

Makna konotasi dalam potongan adegan ini menunjukan tokoh Ben sebagai laki-laki yang maskulin karena dapat mengendalikan amarahnya dan tidak memberikan perlawan terhadap Isabel yang telah meremahkan dirinya. Menurut Chafezt, pengendalian emosi merupakan salah satu ciri maskulinitas. Dalam menghadapi konflik, pengendalian emosi dapat ditunjukan dengan cara saling toleransi diantara kedua pihak. Menurut Arivia (dalam Aryani, 2014), "Toleransi dapat menjadi senjata yang paling ampuh untuk melawan agresifitas, konflik, dan sikap fundamentalis". Sesuai dengan konsep maskulinitas Deborah David dan Robert Brannon yang mengemukakan konsep maskulinitas sebelum tahun 1980-an, yaitu Be a Sturdy Oak yang artinya kelelakian membutuhkan rasionalitas, kekuatan dan kemandirian. Seorang laki-laki harus tetap bertindak kalem dalam berbagai situasi, tidak menunjukkan emosi, dan tidak menunjukkan kelemahannya.

\section{Representasi Intelektual Tokoh Ben Dalam Film Persahabatan Bagai Kepompong}

Menurut konsep Janet Saltzman Chafetz, maskulinitas dapat dilihat dari intelektual laki-laki, yaitu laki-laki memiliki pemikiran yang cerdas, logis, rasional, praktikal, dan objektif. Menurut Hurlock (dalam Huda, 2016) "Seorang remaja dapat mengembangkan keterampilan mengambil keputusan dipengaruhi oleh perkembangan keterampilan intelektual remaja itu sendiri, misal dalam mengambil 
keputusan untuk menikah di usia remaja". Sedangkan menurut Purwanto (dalam Badriyah, 2020) mendefinisikan "Kecerdasan intelektual sebagai kesanggupan untuk beradaptasi kepada kebutuhan baru dengan menggunakan alat-alat berpikir yang sesuai dengan tujuan". Hal ini dapat diartikan apabila seseorang memiliki kecerdasan intelektual yang tinggi maka dirinya akan menggunakan logika untuk berpikir apa yang akan dilakukan dan bagaimana dampak yang diperoleh dari tindakan tersebut. Kecerdasan intelektual kerap berhubungan dengan kemampuan kognitif yang dimiliki oleh individu.

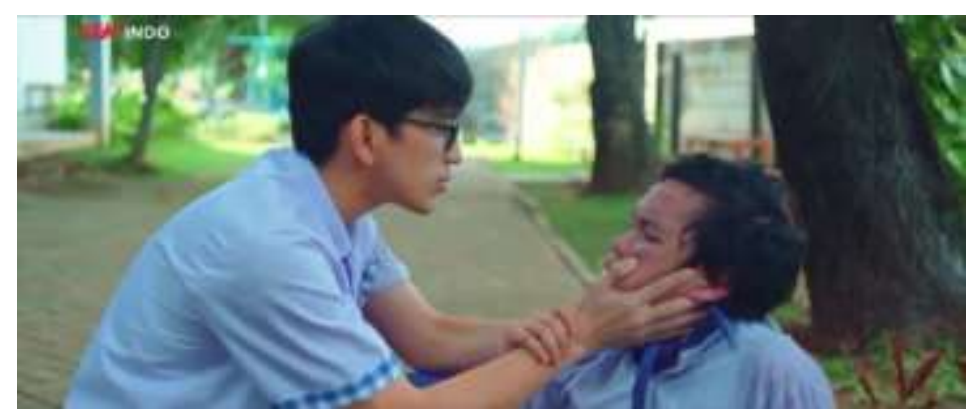

\section{Gambar 10. Ben Sedang Menenangkan Kimo Yang Terbawa Emosi}

Adapun percakapan yang terjadi dalam adegan ini yang menunjukan pemikiran intelektual Ben.

Ben : Hei kamu gak perlu sama kayak mereka. Kamu bisa eksis tanpa jadi Mafioso yang baru. Yang penting kamu bisa menghargai mereka (sambil menunjuk segerombolan teman-temannya).

Dalam percakapan diatas menunjukan Ben memiliki pemikiran intelektual dan mampu berpikir secara objektif. Ben memiliki pemikiran yang logis untuk memberikan arahan dan menyelesaikan masalah yang terjadi. Menurut Rowena \& Rutherford (dalam Dewi, 2019) "Intelektual laki-laki tidak dilihat dari bagaimana laki-laki itu pintar atau tidaknya tetapi dilihat dari bagaimana laki-laki itu menemukan solusi dan memecahkan suatu masalah tertentu".

Makna denotasi dalam potongan adegan diatas menampilkan Ben sedang menenangkan Kimo yang tersulut emosi karena perbuatan Bobby dan teman-temannya. Ben berusaha mengendalikan amarah Kimo dengan cara menyampaikan nasihat agar Kimo tetap berbuat baik. Menurut Barthes, pikiran atau konsep yang dimiliki seseorang adalah sebuah petanda. Pemikiran Ben telah menunjukan sifat intelektual yang dimilikinya, pendapat yang diutarakan Ben menunjukan bahwa ia mempunyai kecerdasan emosi yang tinggi. Menurut Rostiana (dalam Aryani 2014), "Seseorang yang memiliki kecerdasan emosional akan mampu berempati, mengungkapkan dan memahami perasaan, mengendalikan amarah, mandiri, mampu menyesuaikan diri, dan mampu memecahkan masalah antar pribadi".

Mengutip dalam jurnal berjudul Representasi Maskulinitas dalam Iklan Umild "Kode Cowo" milik Linggosiswojo (2016), terdapat aspek representasi yang tidak sesuai dengan stereotip maskulinitas yaitu laki-laki berpenampilan nerd, seperti gemar membaca buku dan susah bergaul. Adanya konstruksi maskulinitas yang digambarkan dengan gaya fashion nerd menunjukkan bahwa maskulinitas tidak hanya dalam bentuk kekuatan fisik saja melainkan juga kekuatan intelektual yang dimiliki.

Makna konotasi dalam potongan adegan ini menunjukan Ben sebagai laki-laki yang maskulin karena dapat berpikir secara rasional dalam situasi yang mendesak, dapat diandalkan karena dirinya selalu bisa menemukan jalan keluar dan solusi yang tepat untuk dirinya dan orang-orang di sekitarnya. Walaupun kalimat yang disampaikan sangat singkat, tetapi tujuannya sangat jelas bahwa Ben ingin menyadarkan Kimo dari situasi tersebut dan ingin Kimo percaya diri dengan apa yang telah dimiliki. 


\section{Representasi Interpersonal Tokoh Ben Dalam Film Persahabatan Bagai Kepompong}

Menurut konsep Janet Saltzman Chafetz, maskulinitas dapat dilihat dari interpersonal laki-laki, yaitu laki-laki membentuk dirinya menjadi bertanggungjawab, disiplin, mandiri, bebas, berjiwa pemimpin, individualis, serta mendominasi.

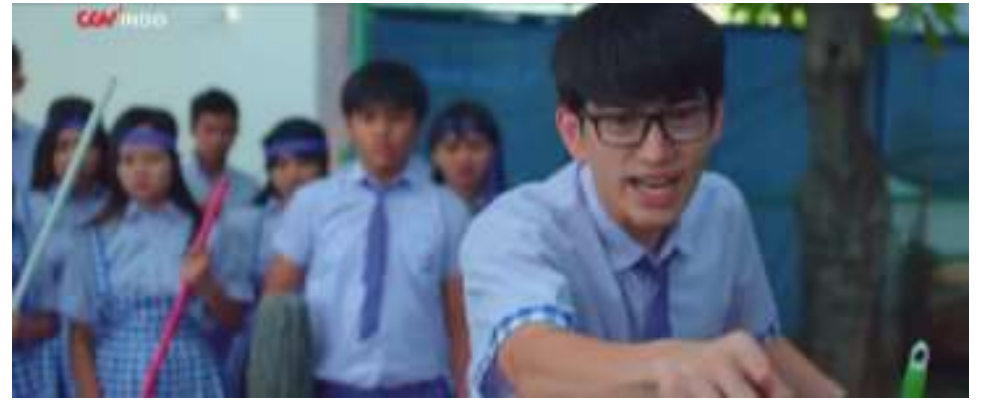

\section{Gambar 11. Ben Bersama Segerombolan Teman-Temannya}

Adapun percakapan yang terjadi dalam adegan ini, saat Ben berusaha melerai Kimo.

Ben : Cukup Kimo! Gak kayak gini caranya

Kimo : Gua sekalian bales dendam lu, Ben! Dia kan yang ngerebut Paula dari lu kan?

Ben : Bukan kimo, bukan dia. Emang Paula aja gak mau sama aku

Kimo : Nggak Ben, ngaku deh! Ini orang dari dulu pengen gue hajar!

Ben : Kimo!! kalo kamu mukul dia, kamu sama aja kayak dia, gak ada bedanya

Makna denotasi dalam potongan adegan ini menampilkan Ben bersama teman-temannya ingin menghentikan Geng Mafioso dan melindungi salah satu temannya, yaitu Kimo yang saat itu sedang terlibat pertengkaran. Tujuan Ben membawa teman-temannya adalah untuk membantu dirinya dan waspada jika dirinya terancam. Tetapi dalam adegan diatas, Ben mampu memberikan nasihat dan melerai teman-temannya walaupun hanya dengan perkataan saja.

Melindungi tidak harus menggunakan kekerasan fisik terhadap seseorang, hal lain dapat dilakukan dengan cara memberikan saran dan masukan. Menurut Ningtriasih (dalam Pratami \& Prima, 2020), "Perbedaan cara berpikir pria dengan wanita, yakni dalam hal komunikasi pria cenderung lebih to the point, hal ini memberikan kesan pada pria talk less do more yang berarti sikap sedikit berbicara banyak bekerja, meski kerap dianggap membingungkan namun hal ini cukup efektif bagi pemimpin dan menunjukkan kewibawaan seorang pria". Makna konotasi dalam potongan adegan ini menampilkan Ben sebagai laki-laki yang maskulin, yaitu menunjukan sifat kepemimpinan dengan berupaya melerai dan menengahi pertengkaran antara Kimo dan Bobby tanpa melakukan kekerasan. Walaupun hanya bisa melerai dengan perkataan, ucapan yang disampaikan Ben menunjukan bahwa dirinya dapat dipercaya, tidak gengsi, dan berani mengakui kelemahan dirinya yang telah ditolak oleh Paula.

Sifat maskulinitas yang nampak pada representasi laki-laki sebagai pemimpin adalah Give em Hell, yaitu sifat laki-laki yang menunjukan keberanian, agresif, dan mampu mengambil resiko. Ketika tersandung masalah, seringkali laki-laki cenderung melakukan perlawan terhadap musuhnya dengan melakukan kekerasan. Mitos dalam potongan adegan diatas menunjukkan Ben dapat menyelesaikan masalah dengan pikiran bukan dengan otot.

\section{Representasi Karakter Personal Tokoh Ben Dalam Film Persahabatan Bagai Kepompong}

Menurut konsep Janet Saltzman Chafetz, maskulinitas dapat dilihat dari karakter personal 
laki-laki, yaitu laki-laki memiliki sifat yang ambisius, berkeinginan sukses, egoistik, moral, dapat dipercaya, berjiwa kompetitif, dan berjiwa petualang.

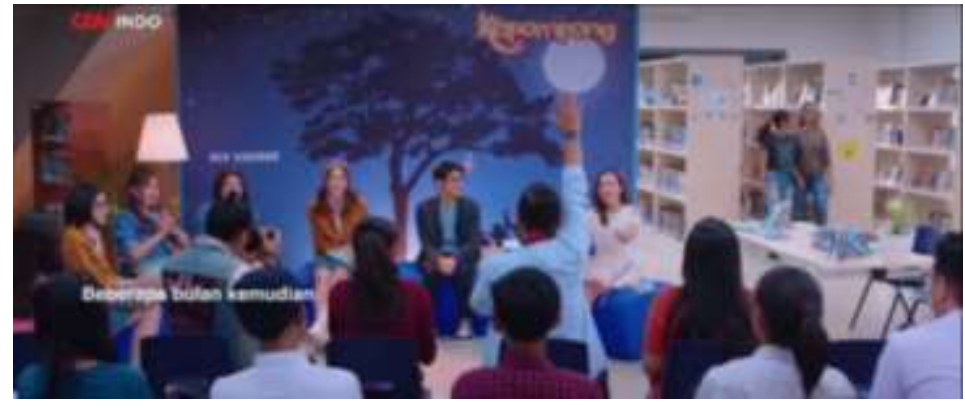

\section{Gambar 12. Ben sedang melaksanakan Konferensi Pers}

Makna denotasi dalam potongan adegan ini menampilkan Ben bersama dengan temantemannya melakukan press conference dengan para wartawan dan pengunjung untuk perilisan buku novelnya yang berjudul Kepompong.

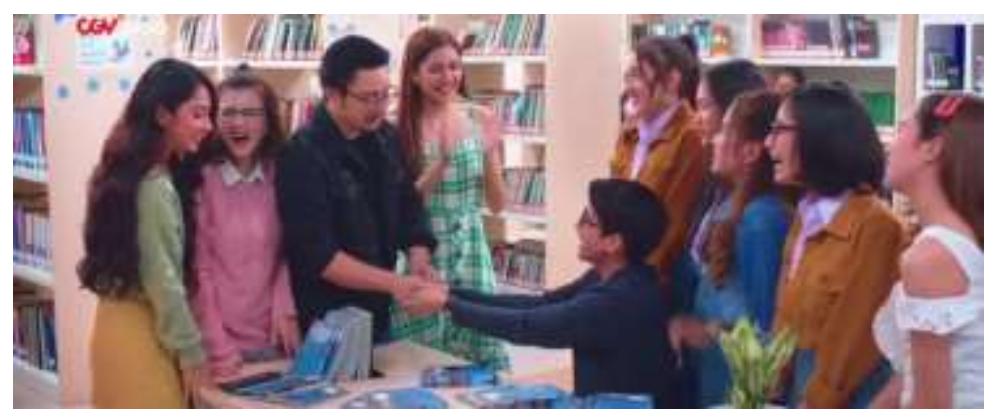

\section{Gambar 13. Ben melakukan penandatanganan buku novelnya}

Setiap laki-laki memiliki karakter personal masing-masing dan berbeda. Makna konotasi dalam potongan adegan ini menunjukan maskulinitas Ben ditampilkan sebagai sosok yang ambisius dan kompetitif dalam mewujudkan mimpinya menjadi seorang penulis novel. Ben berhasil membuat novel berdasarkan pengalaman pribadinya tanpa terpengaruh oranglain. Menurut Kamus Besar Bahasa Indonesia (dalam Amalia, 2020) "Ambisius memiliki arti berkeinginan keras mencapai sesuatu (harapan, cita-cita); penuh ambisi”.

Sedangkan, Deborah David dan Robert Brannon mengemukakan konsep maskulinitas sebelum tahun 1980-an adalah Be a Big Wheel, yaitu maskulinitas dapat diukur dari kesuksesan, kekuasan, dan pengaguman dari orang lain. Seseorang harus mempunyai kekayaan, ketenaran, dan status yang sangat lelaki. Konsep tersebut tidak sesuai dengan penggambaran maskulinitas tokoh Ben. Ben mampu menjadi seorang laki-laki yang sukses tanpa terpengaruh oleh kondisi lingkungan dan hidupnya yang digambarkan menjadi seorang anak yatim. Mitos yang terdapat pada adegan di atas menunjukkan bahwa Ben mampu bangkit dan menghadapi permasalahannya secara optimis untuk mewujudkan mimpi, menjalani hidupnya dengan lebih baik, serta meraih masa depan yang sukses.

\section{4 | SIMPULAN DAN SARAN}

Representasi laki-laki maskulin tidak harus ditunjukan dengan penampilan yang berotot, mendominasi perempuan, kasar, macho, sukses, dan kaya raya. Maskulinitas laki-laki juga dapat 
dilihat melalui kedewasaan, kemandirian, hingga prestasi yang dicapai. Penampilan laki-laki tidak bisa dinilai hanya dengan melihat sifat yang dimiliki laki-laki, seperti lugu, cupu, lembut, dan polos. Bukan berarti laki-laki yang memiliki sifat seperti itu tidak maskulin. Hal ini dibuktikan dari penggambaran tokoh utama laki-laki, yaitu Ben Sarjono dalam film Persahabatan Bagai Kepompong yang tayang pada tahun 2021 di Disney Plus Hotstar. Penggambaran Maskulinitas Ben Sarjono dalam Film Persahabatan Bagai Kepompong tetap digambarkan sebagai laki-laki maskulin meskipun sifatnya cenderung berbeda dengan sifat laki-laki pada umumnya. Ben cenderung menjadi seorang remaja laki-laki yang lebih tenang, lembut, pasrah menerima keadaan, tertutup, serta individualis. Kehidupan Ben mulai berubah setelah ia pindah sekolah ke Jakarta. Berteman dengan Kimo dan Geng Kepompong, Ben menjadi lebih terbuka dan paham tentang artinya pertemanan. Untuk peneliti selanjutnya yang akan membahas film Persahabatan Bagai Kepompong. Penulis berharap dapat mengembangkan film Persahabatan Bagai Kepompong menjadi studi efek penonton setelah melihat film Persahabatan Bagai Kepompong dan dapat membahas secara khusus tentang dampak tayangan film Persahabatan Bagai Kepompong terhadap penontonnya. Sehingga terdapat kesinambungan antara gambaran penelitian dan dampak setelah menonton film Persahabatan Bagai Kepompong. Semoga penelitian ini dapat bermanfaat dan berfungsi dengan baik, serta dapat memperbanyak topik penelitian dalam bidang kajian studi media perfilman.

\section{REFERENSI}

Amalia, M. (2020). Representasi Maskulinitas Laki-Laki Difabel Dalam Film Paafekuto Waarudo. Universitas Diponegoro.

Aryani, S. P. (2014). Representasi Maskulinitas Laki-Laki Infertil Dalam Film Test Pack Karya Ninit Yunita. Universitas Airlangga.

Badriyah, L. (2020). Pengaruh Gender, Kecerdasan Intelektual, Kecerdasan Emosional, Dan Kecerdasan Spiritual Terhadap Sensitivitas Etis Mahasiswa Akuntansi.

Budiastuti, A., \& Wulan, N. (2014). Konstruksi Maskulinitas Ideal Melalui Konsumsi Budaya Populer oleh Remaja Perkotaan. Mozaik Humaniora, 14.

Dewi, P. N. (2019). Representasi Maskulinitas Dalam Film Aquaman. Universitas Muhammadiyah.

Dicky, D. F. R. (2016). Representasi Budaya Populer Dalam Film "Slank Nggak Ada Matinya" Karya Fajar Bustomi. EJournal Limu Komunikasi, 4(3), 344-358.

Fadaq, H. (2017). Representasi Indonesia Dalam Iklan Audio Visual (Analisis Semiotika Pada Iklan Wonderful Indonesia Versi 'The Limitless Wonderful Words To Portray Indonesia').

Universitas Muhammadiyah Malang.

Huda, N. (2016). Kemandirian pada Remaja yang Diasuh Orangtua Tunggal. Fakultas Psikologi.

Istanti, L. (2021). Representasi Persahabatan Dalam Film "Koki-Koki Cilik 2." Universitas Islam Negeri Sunan Ampel Surabaya.

Linggosiswojo, S. G. (2016). Representasi Maskulinitas dalam Iklan Umild "Kode Cowo." Jurnal EKomunikasi, 4, 1-12.

Makarim, F. R. (2021). Berapa Tinggi Badan Ideal untuk Anak Laki-Laki? Halodoc.Com.

Nurgiyantoro, B., Lestyarini, B., \& Rahayu, D. H. (2020). Konstruk Asesmen Literasi Fungsional Untuk Siswa Sekolah Menengah Pertama. Litera, 19(2).

https://doi.org/10.21831/LTR.V19I2.32977

Nurhayati, T. (2016). Perkembangan Perilaku Psikososial Pada Masa Pubertas. Edueksos - Jurnal Pendidikan Sosial \& Ekonomi.

Pratami, R., \& Prima, T. H. (2020). Representasi Maskulinitas Pria dalam Iklan Televisi Men's Biore Cool Oil Clear. Jurnal Komunikasi, 14. https://doi.org/http://dx.doi.org/10.20885/komunikasi.vol11.iss1.art1

Rosi, R. (2018). Pengaruh Maloklusi Gigi Terhadap Status Psikososial Pada Smp Islam (Studi 
Terhadap Siswa Smp Islam Sultan Agung 4 Semarang). Fakultas Kedokteran Gigi.

Ryoningrat, R., \& Herdiyanto, Y. K. (2019). Hubungan intensitas menonton film porno terhadap maskulinitas remaja laki-laki di Bali. Jurnal Psikologi Udayana, 6(01), 11-20. https://doi.org/10.24843/JPU.2019.V06.101.P02

Sari, D. P., Effendy, C., \& Wartiningsih, A. (2019). Maskulinitas Tokoh Utama Dalam Kumpulan Cerita Pendek Nadira Karya Leila S. Chudori. Jurnal Pendidikan Dan Pembelajaran Khatulistiwa, 8(2).

Setiyaningsih, L. A., \& Jatmikowati, S. H. (2019). Media Baru Dalam Komodifikasi Waktu Luang Ibu Rumah Tangga. ETTISAL: Journal of Communication, 4(1), 23-32.

Setiyaningsih, L. A. (2020). MEDIA PANICS IBU RUMAH TANGGA SETELAH MENGAKSES BERITA COVID-19 (2020). Jurnal Nomosleca, 6(2), 101-110.

http://jurnal.unmer.ac.id/index.php/n/article/view/4721/2594

Setiyaningsih, L. A., Fahmi, M. H., \& Molyo, P. D. (2021). Selective Exposure Media Sosial Pada Ibu dan Perilaku Anti Sosial Anak. Jurnal Komunikasi Nusantara, 3(1), 1-11. https://doi.org/10.33366/jkn.v3i1.65

Syulhajji S. (2017). Representasi Maskulinitas Dalam Film Talak 3 (Studi Analisis Semiotika Roland Barthes). EJournal IImu Komunikasi, 5.

Triono, M. A., \& Setiyaningsih, L. A. (2017). Desain Disonansi Kognitif Sebagai Faktor Anteseden Untuk Penguatan Kualitas Informasi Pada Website. Seminar Nasional Sistem Informasi, 1(1), 71-79. http://eprints.unmer.ac.id

Yusanta, D. A. (2019). Fluiditas Maskulinitas dan Feminitas dalam Boyband K-Pop sebagai Produk Industri Budaya. Kafa`ah: Journal of Gender Studies, 9(2), 205.

https://doi.org/10.15548/JK.V9I2.294 